\title{
Solar Energy Potential in Nepal and Global Context
}

\author{
Krishna R. Adhikari ${ }^{1 *}$, Shekhar Gurung ${ }^{2}$, Binod K. Bhattarai ${ }^{3}$ \\ ${ }^{I}$ Pashchimanchal Campus, Institute of Engineering, Tribhuvan University, Nepal \\ ${ }^{2}$ Central Department of Physics, University Campus, Tribhuvan University, Nepal \\ ${ }^{3}$ Department of Engineering Science and Humanities, Institute of Engineering, Central Campus, Pulchowk, \\ Tribhuvan University, Nepal \\ *Corresponding Email: adhikarikrishna@ioe.edu.np
}

\begin{abstract}
Solar radiation is the best option and cost effective energy resources of this world from $21^{\text {st }}$ century onwards. In this study monthly, seasonal and annual variation of global solar insolation at Biratnagar, Lukla, Kathmandu, Pokhara, of the year 2007 to 2012, Jumla of the year 2011 to 2012 and Simikot 2011/2012 were carried out. The study has shown the variation of global solar insolation with month, season, year, atmospheric condition, and altitude of the site concerned. The maximum value of monthly, seasonal, and yearly global solar insolation was reported at Jumla whereas the minimum monthly, seasonal, and yearly global solar insolation were observed at Kathmandu. From the observation the abundant solar irradiation in Nepal shows encouraging atmosphere for solar farming venture in near future relating to energy management for Nepal.
\end{abstract}

Keywords: Solar insolation, global solar radiation, alternative energy, solar farming

\section{Introduction}

Energy, food, minerals, trained human resources, financial status and fresh water are the major components to develop a country whereas energy and fresh water are the two major and fundamental commodities [16] to assure the better life quality of human beings. By understanding the position and significance of these resources and deliberate/wise exploitation of them can change the face of the country and the livelihood of the people.

Nepal is a landlocked country, with small span, surrounded three sides by India and one side by China. Within this small and beautiful setting it possesses diversity in biosphere, climate (arctic/alpine to tropical) and landscape (lowland $72 \mathrm{~m}$ to highest peak $8848 \mathrm{~m}$ high above the sea level). It does not have its own coal and petroleum resources so far and has no access to the sea/ocean. For the last six years till now fossil fuel prices have hiked an all time-high and the world is forced into its deepest recession since the Great Depression. Geopolitical events are driving prices steadily higher. The short-term risks to political stability and economic activity posed by the world's dependence on fossil fuels are again as manifest as its long-term threat to environmental sustainability. To break this dependency, all the countries in the world need a clean energy revolution. Such a revolution would enhance global energy security, promote longterm economic growth and tackle environmental challenges such as anthropogenic climate change [6]. Available literature tells that consumption of petroleum products in Nepal is increasing wonderfully at the rate of about $10 \%$ per year (Source: NOC, 2011), so the information is not as fine as it should be.

Solar radiation, one of the major fuel sources, occurs abundantly everywhere and also in Nepal. Surface incident solar radiation governs/drives the atmospheric circulations, Earth's climate [17], 
and Earth's biosphere naturally. It is also the originator of all other sources of energy that exists on the face of this earth. Even the most widely used energy resources today like fossil fuels, are an indirect result of trapped Sun's energy over the time. It runs solar energy devices and generates electricity as one of the best clean and alternative energies.

In the fiscal year 2008/09 total energy consumption in Nepal was 410,000 TJ. The consumption coverage data provided by MOF shows $85 \%$ coverage by traditional resources (i.e., biomass energy resources), $14 \%$ by commercial sources (petroleum products- $9 \%$, coal-3 $\%$ and grid electricity- $2 \%$ ) and about $1 \%$ by alternative sources (biogas, solar power, wind and micro/pico level hydropower) [9]. The average global solar radiation in Nepal varies from 3.6-6.2 $\mathrm{kWh} / \mathrm{m}^{2}$ day, sun shines for about 300 days a year, the number of sunshine hours amounts almost 2100 hours per year and average insolation intensity about $4.7 \mathrm{kWhm}^{-2} \mathrm{day}^{-1}\left(=16.92 \mathrm{MJ} / \mathrm{m}^{2}\right.$ day $)$ [18] it is greater than $4.38 \mathrm{kWh} / \mathrm{m}^{2}$ day $\left(15.8 \mathrm{MJ} / \mathrm{m}^{2}\right.$ day) measured by [15] for Lao PDR. Thus, Nepal lies in a favourable insolation zone in the world even though the data in Nepal was based on one year and few sites [18] but that of Lao PDR was based on few years and throughout the country. So, a long term and many sites' solar energy data are required to authenticate this statement.

As to the above consideration the total energy generation potential of the country with total area 147,181 square kilometers will be $83,000 \mathrm{GWh} /$ day $=18.36 \mathrm{TW}$ with the conjecture of $12 \%$ efficiency of Photo Voltaic (PV) module. This is more than present energy demand (=13 TW) [18] of the world. Thus, solar energy with a huge potential to meet many times the present world energy demand is a best alternative to fossil fuels for more sustainable and reliable energy options. Readily available solar radiation data is a key to designing and simulation of all solar energy applications.

The installed capacity of power plants connected to the national grid is $689.3 \mathrm{MW}$ whereas peak demand of power for the year 2011/12 was $1056.90 \mathrm{MW}$ and projection of power demand for 2012/13 and 2013/14 are 1163.20 MW and 1271.70 MW respectively [11] even though its theoretical, technical and economical feasible hydropower potential has been estimated at about 83000 MW, 45000 MW and 42000 MW respectively [18]. In the real practice the energy sources are limited in one hand and on the other hand $1.35 \%$ of population growth rate in Nepal creates further pressure on extra energy demand. The electricity consumption and the number of consumers increase at a rate of approximately $9 \%$ per year [12] whereas generation of additional power plant is almost in stagnant situation and immediate and critical management is also not viable.

Easily available and inextinguishable nature of solar energy resource resides in one of the imperative places among the various possible alternative energy sources [4]. An accurate data base of solar radiation at particular places and selected sites are required for the development, simulations and designing of many solar energy devices/applications and establishment of solar plants as well [1].

Under this circumstance and knowing the fact that $52 \%$ of the Nepalese households have no access to electricity [12], flourishing of solar irradiance data are essential for the development of national rural energy programs in general and for the establishment of solar energy technology in particular. For an extensive investment in these technologies from government and private sectors [3] is not only desirable but it is the ultimate options where there is no viable alternative to the solar electricity. 
In this study the global solar energy at six different sites of Nepal, from lowland/tropical region (south) to High Mountain/alpine (north) and from east to west, for few years' data were observed and analyzed. The global solar insolations of these locations were compared to each other and the derived national average solar radiation has been compared with global context as well. Moreover, ground based measured data are compared with earlier data presented by [3] and [14].

\section{The Study Sites}

The locations selected covered the lowland/plain (south) to the high mountain (north) and east to west of Nepal for measuring the solar radiation. These selected sites cover the wide range of altitude from $72 \mathrm{~m}$ to $2,850 \mathrm{~m}$ above the sea level. The sites, from east to west, of Nepal are briefly introduced as given below.

Biratnagar lies at latitude $26.483^{\circ}$, longitude $87.266^{\circ}$, and in the eastern region of Nepal at the altitude of $72 \mathrm{~m}$ from the sea level. Its climate is closer to tropical and extremely hot up to the 40 ${ }^{\circ} \mathrm{C}$ and humid in summer and very cold and foggy in winter where the minimum temperature is about $10^{\circ} \mathrm{C}$. Its total precipitation is about $1300 \mathrm{~mm}$ to $2780 \mathrm{~mm}$ per year (Source: DHM/GoN) which varies annually.

Lukla lies near Mount Everest area at latitude $27.68^{\circ}$, longitude $86.73^{\circ}$, and at the altitude 2, $850 \mathrm{~m}$ above the sea level. Its climate is sub-tropical, wet summers and chilly, dry winters are mainly affected by its altitude and the summer monsoon season. The temperature ranges between $4^{\circ}$ to $27^{\circ} \mathrm{C}$ in summer and $-15^{\circ}$ to $6{ }^{\circ} \mathrm{C}$ in winter.

Kathmandu is the capital city located at latitude $27.7^{\circ}$, longitude $86.366^{\circ}$ and almost at the middle of Nepal at the altitude 1, $337 \mathrm{~m}$ above from the sea level. This Valley falls under the Warm Temperate Zone. The average temperature in summer ranges from $28^{\circ}$ to $30^{\circ} \mathrm{C}$ and 3 to $10.1{ }^{\circ} \mathrm{C}$ in winter. The total precipitation is about $1,205 \mathrm{~mm}$ to $1871 \mathrm{~mm}$ per year (Source: $\mathrm{DHM} / \mathrm{GoN})$. The air quality of Kathmandu Valley is deteriorating. The visibility level decreases at the rate of $1.2 \mathrm{~km} /$ year. This obviously shows that fine particulate level in the Valley has increased at a very high rate. This may be associated with road traffic and various types of construction works [14].

Pokhara is located at latitude $28.216^{\circ}$, longitude $84^{\circ}$ and in the western part of Nepal and at the altitude $827 \mathrm{~m}$ from the sea level. It is a Sub-Metropolitan City that lies in warm and cold moderate climatic zone. And the total precipitation is about $2967 \mathrm{~mm}$ to $4785 \mathrm{~mm}$ per year (Source: DHM/GoN) which is the highest in Nepal. The temperature ranges from 25 to $35{ }^{\circ} \mathrm{C}$ in summer, and 2 to $15^{\circ} \mathrm{C}$, in winter.

Jumla lies at latitude $29.283^{\circ}$, longitude $82.166^{\circ}$ and in the mid western region and at the altitude 2, $300 \mathrm{~m}$ above the sea level. It lies in alpine climatic zone and temperature varies from $7.8{ }^{\circ} \mathrm{C}$ in winter to $30.8{ }^{\circ} \mathrm{C}$ in summer. Its total precipitation is about $670 \mathrm{~mm}$ to $967 \mathrm{~mm}$ per year (Source: DHM/GoN) whereas the average rainfall of Nepal is $1857.6 \mathrm{~mm}$ per year, but with sharp spatial and temporal variations both north-south and east-west [10].

Simikot lies at latitude $29.97^{\circ}$, longitude $81.83^{\circ}$ and in the mid western region and at the altitude 2, $800 \mathrm{~m}$ above the sea level. It lies in alpine climatic zone and temperature varies from ${ }^{\circ} \mathrm{C}$ in winter to ${ }^{\circ} \mathrm{C}$ in summer. Its total precipitation is about $150 \mathrm{~mm}-200 \mathrm{~mm}$ per year (Source: [10]) 
The monsoon rain is most abundant in the east and declines westwards; while winter rains are higher in the northwest and decline south-eastwards. Rainfall maximums are located in the areas around Pokhara and northeast and east of the Kathmandu valley [10]. The temperature in Nepal varies with altitude and season: in general, the temperature increases from north to south with decreasing altitude. The winter season is coldest, with the highest temperatures during premonsoon.

\section{Methods and Materials}

The primary data of daily solar radiation, on horizontal surface for Biratnagar, Lukla, Kathmandu, Pokhara, Jumla and Simikot were collected from the archives of the Department of Hydrology and Meteorology, government of Nepal (DHM/GoN) and Solar Radiation and Aerosol in Himalayan Region (SAHR) project of Institute of Engineering, Tribhuvan University, Nepal. Rain fall data for these sites were obtained from Department of Hydrology and Meteorology (DHM)/GoN. The data obtained covered a period of years from 2007 to 2012 for Biratnagar, Kathmandu, Pokhara, and two years 2011 to 2012 years for Jumla and Simikot. The most widely used ORIGIN/Microsoft Office Excel software has been used for the data analysis.

\section{Theory}

Solar insolation outside the earth's atmosphere at the mean distance between the earth and the sun [8] is termed as solar constant $\left(\mathrm{I}_{\mathrm{sc}}\right)$ given by [7]:

$$
\mathrm{I}_{\mathrm{sc}}=1367 \mathrm{~W} / \mathrm{m}^{2}
$$

It varies with the distance between the earth and the sun and sunspot activities whereas the variation is a very small quantity over a period of years.

The solar insolation/irradiance on a horizontal surface is depend initially on solar zenith angle $\left(\theta_{z}\right)$ given by [7] and [5] as

$$
I_{0}=I_{s c} E_{0} \cos \theta_{z}=I_{s c} E_{0}(\sin \delta \sin \phi+\cos \delta \cos \phi \cos \omega)
$$

Where,

$$
\begin{aligned}
& \cos \theta_{z}=\sin \delta \sin \phi+\cos \delta \cos \phi \cos \omega \\
& E_{0}=1+0.33 \cos \frac{360 N}{365}
\end{aligned}
$$

is the eccentricity correction,

$\mathrm{N}$ is the day number of the year (DoY) (for $1^{\text {st }} \mathrm{Jan}, \mathrm{N}=1$ and for $31^{\text {st }}$ Dec, $\mathrm{N}=365$ ),

$\emptyset$ is the latitude of the site,

$$
\delta=23.45 \sin \left[\frac{360(N+284)}{365}\right]
$$

is the solar declination,

For short interval of time dt the irradiance will be

$$
d I_{0}=I_{s c} E_{0} \cos \theta_{z} d t
$$


The $I_{s c}$, solar constant without over dot is in the energy unit $\mathrm{MJ} / \mathrm{m}^{2} \mathrm{hr}$. The time in hour can be converted into hour angle $\omega$ as follow:

$$
\begin{aligned}
& d t=\frac{12}{\pi} d \omega \\
& \left(\because \text { rotational speed of the earth around its polar axis is } \frac{2 \pi}{24 \text { hour }}=\frac{d \omega}{d t}\right)
\end{aligned}
$$

The extraterrestrial radiation $I_{0}$ over the period of one hour is obtained by integrating the equation (5),

$$
\therefore I_{0}=I_{s c} E_{0}\left(\sin \phi \sin \delta+\cos \phi \cos \delta \sin \omega_{i}\right)
$$

Here, $\omega_{i}$ is the hour angle.

Similarly daily extraterrestrial radiation on a horizontal surface is given as:

$$
\begin{aligned}
& H_{0}=\int_{S r}^{S S} I_{0} d t \\
& \quad[\text { sr and ss stand for sunrise and sunset] } \\
& \therefore H_{0}=\frac{24}{\pi} I_{S c} E_{0}\left[\frac{\pi}{180} \omega_{s} \sin \phi \sin \delta+\cos \phi \cos \delta \sin \omega_{s}\right]
\end{aligned}
$$

Here,

$$
\begin{array}{r}
I_{s c}=\frac{1367 \times 3600}{1000000} M J / m^{2} h \\
\text { is the solar constant, } \\
\omega_{s}=\cos ^{-1}(-\tan \phi \tan \delta)
\end{array}
$$

is the hour angle in degrees,

$$
N_{d}=\frac{2}{15} \cos ^{-1}(-\tan \phi \tan \delta)=\frac{2}{15} \omega_{s}
$$

is the maximum possible sunshine hours.

The radiation $\left(H_{0}\right)$ enters the atmosphere which is greatly modified by the clouds, atmosphere and its constituents such as water vapor, ice, aerosols etc to obtain the ground based measured radiation $H_{m}$ on the horizontal surface, where the ratio $\frac{H_{m}}{H_{0}}=K_{T}$ is called clearness parameter or cloudiness index, depends on the condition of the sky [2].

The data obtained from the Department of Hydrology and Meteorology, Government of Nepal (DHM/GoN) and Solar Radiation and Aerosol in Himalayan Region (SAHR) project is processed to monthly sum and monthly mean daily global solar radiation, seasonal sum and mean daily solar radiation, yearly sum and mean daily solar radiation for Biratnagar, Lukla, Kathmndu, Pokhara, Jumla and Simikot of Nepal. The data are compared with [14], [3] and with global context. 


\section{Result and Discussion}

\subsection{Monthly Solar Radiation}

Table 1: Monthly sum global solar radiation for six sites from 2008 to 2012

\begin{tabular}{|c|c|c|c|c|c|c|}
\hline Month & BRT & LUKLA & KTM & PKR & JULMA & SIMIKOT \\
\hline JAN & 285.00 & 475.33 & 336.51 & 379.67 & 467.17 & 404.59 \\
\hline FEB & 350.77 & 460.95 & 355.25 & 413.62 & 471.28 & 381.86 \\
\hline MAR & 491.00 & 520.74 & 455.01 & 517.97 & 693.76 & 446.99 \\
\hline APR & 538.72 & 581.68 & 508.90 & 564.31 & 684.19 & 508.88 \\
\hline MAY & 583.40 & 510.84 & 537.65 & 664.13 & 781.36 & 373.64 \\
\hline JUN & 518.16 & 425.02 & 496.89 & 634.72 & 749.16 & 370.81 \\
\hline JUL & 475.18 & 293.03 & 444.18 & 529.71 & 619.68 & 511.52 \\
\hline AUG & 435.32 & 242.33 & 414.78 & 531.42 & 595.99 & 592.49 \\
\hline SEP & 446.34 & 278.41 & 405.85 & 501.53 & 657.80 & 1233.30 \\
\hline OCT & 454.12 & 556.31 & 424.69 & 542.57 & 620.88 & 465.95 \\
\hline NOV & 345.10 & 505.50 & 334.70 & 389.50 & 501.80 & 436.80 \\
\hline DEC & 317.40 & 438.50 & 311.00 & 360.90 & 436.50 & 366.10 \\
\hline
\end{tabular}

The observed data presented in Table 1 shows that monthly sum minimum global solar insolation were recorded as $285 \mathrm{MJ} / \mathrm{m}^{2}$ in Jan for Biratnagar, 242.33 MJ/m² in August for Lukla, $311.00 \mathrm{MJ} / \mathrm{m}^{2}$ in December for Kathmandu, $360.60 \mathrm{MJ} / \mathrm{m}^{2}$ in December for Pokhara, 436.50 $\mathrm{MJ} / \mathrm{m}^{2}$ in December and 366.10 $\mathrm{MJ} / \mathrm{m}^{2}$ in December for Simikot.

Likewise monthly sum maximum global solar radiation were observed as $583.40 \mathrm{MJ} / \mathrm{m}^{2}$ in May, $581.68 \mathrm{MJ} / \mathrm{m}^{2}$ in April, 537.65 MJ/m $\mathrm{m}^{2}$ in May, 664.12 MJ $/ \mathrm{m}^{2}$ in May, $781.36 \mathrm{MJ} / \mathrm{m}^{2}$ in May and $1233.30 \mathrm{MJ} / \mathrm{m}^{2}$ in September (Unusual value) for Biratnagar, Lukla, Kathmandu, Pokhara, Jumla, and simikot respectively. From the above data it is observed that the minimum value of global solar radiation were recorded in November, December, January and February characterize the relatively shorter days, farthest distance of the earth from the sun, more cloud cover skies, and more foggy days. Among these locations the least value of minimum global solar radiation was recorded $169.90 \mathrm{MJ} / \mathrm{m}^{2}$ in June 2008 at Kathmandu shows the most unclear, cloudy sky and rainy circumstance (Average rain fall $7.34 \mathrm{~mm}$ per day. Source: DHM/GoN) of the Kathmandu Valley. 
Table 2: Monthly mean daily global solar radiation in $\mathrm{MJ} / \mathrm{m}^{2}$ day for six sites from 2008 to 2012

\begin{tabular}{|c|c|c|c|c|c|c|}
\hline Month & BRT & LUKLA & KTM & PKR & JULMA & SIMIKOT \\
\hline JAN & 9.193 & 15.33 & 10.86 & 12.25 & 15.07 & 13.05 \\
\hline FEB & 12.37 & 16.46 & 12.51 & 14.57 & 16.542 & 13.17 \\
\hline MAR & 15.84 & 16.8 & 14.68 & 16.71 & 22.379 & 14.42 \\
\hline APR & 17.96 & 19.39 & 16.96 & 18.81 & 22.806 & 16.96 \\
\hline MAY & 18.82 & 16.48 & 17.34 & 21.42 & 25.205 & 12.05 \\
\hline JUN & 17.27 & 14.17 & 16.56 & 21.16 & 24.972 & 12.36 \\
\hline JUL & 15.33 & 9.453 & 14.33 & 17.09 & 19.99 & 16.50 \\
\hline AUG & 14.04 & 7.817 & 13.38 & 17.14 & 19.225 & 19.11 \\
\hline SEP & 14.88 & 9.28 & 13.53 & 16.72 & 21.927 & 41.11 \\
\hline OCT & 14.65 & 17.95 & 13.70 & 17.50 & 20.028 & 15.03 \\
\hline NOV & 11.5 & 16.8 & 11.20 & 13.00 & 16.73 & 14.56 \\
\hline DEC & 10.2 & 14.1 & 10.00 & 11.60 & 14.30 & 11.81 \\
\hline
\end{tabular}

The minimum monthly mean daily global solar radiation (GSR) were recorded as 9.193 $\mathrm{MJ} / \mathrm{m}^{2}$ day in Jan, $9.28 \mathrm{MJ} / \mathrm{m}^{2}$ day in September, $12.25 \mathrm{MJ} / \mathrm{m}^{2}$ day in January, $11.60 \mathrm{MJ} / \mathrm{m}^{2}$ day in December, $14.30 \mathrm{MJ} / \mathrm{m}^{2}$ day in December, and $11.81 \mathrm{MJ} / \mathrm{m}^{2}$ day in December for Biratnagar, Lukla, Kathmandu, Pokhara, Jumla and Simikot respectively. Similarly, the maximum monthly mean daily global solar radiation were recorded as $18.82 \mathrm{MJ} / \mathrm{m}^{2}$ day in May, $19.39 \mathrm{MJ} / \mathrm{m}^{2}$ day in April, 17.34 in May, $21.42 \mathrm{MJ} / \mathrm{m}^{2}$ day in May, $25.205 \mathrm{MJ} / \mathrm{m}^{2}$ day in May, and $41.11 \mathrm{MJ} / \mathrm{m}^{2}$ day (Unusual Data) in September for Biratnagar, Lukla, Kathmandu, Pokhara, Jumla and Simikot respectively. The peak solar insolation occurs in April to July and least value occurs in January, February, November and December. Unusual data were recorded only in September for Simikot due to either instrumental error, or some strong light source/reflector might be present close to the instrument. It was manifested that Jumla is the location where the maximum global solar energy was observed. Moreover all the sites in Nepal are solar radiation friendly locations i.e., ample global solar radiation were recorded.

\subsection{Seasonal Solar Radiation}

Figure 1 is the Seasonal plotting of global solar radiation of six different sites of Nepal. The plots show that minimum value of seasonal sum global solar radiation $545.05 \mathrm{MJ} / \mathrm{m}^{2}$ and seasonal mean daily global solar radiation $5.92 \mathrm{MJ} / \mathrm{m}^{2}$ day were observed at Kathmandu in summer 2007/2008. Maximum value of seasonal sum global solar radiation $2176.93 \mathrm{MJ} / \mathrm{m}^{2}$ and seasonal mean daily global solar radiation $23.66 \mathrm{MJ} / \mathrm{m}^{2}$ day were observed for Jumla in summer 2010/2011. But, usually minimum value was recorded in winter and maximum value in spring season at all the locations besides Simikot. 


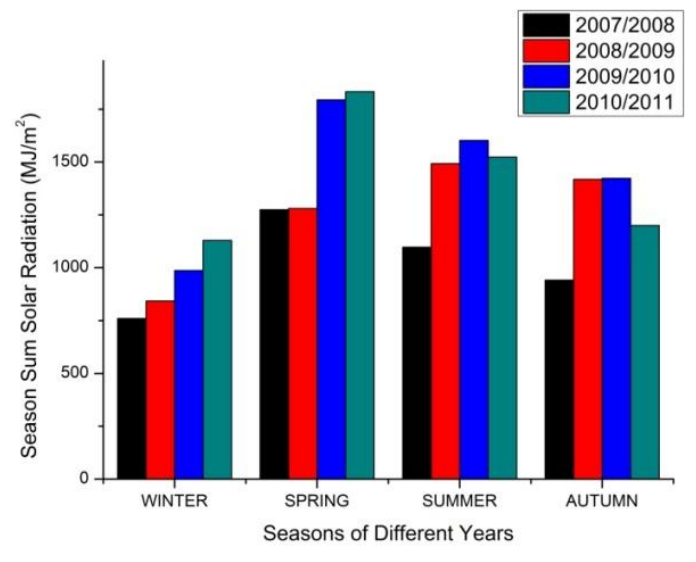

Figure 1.a: Seasonal Sum GSR of Biratnagar

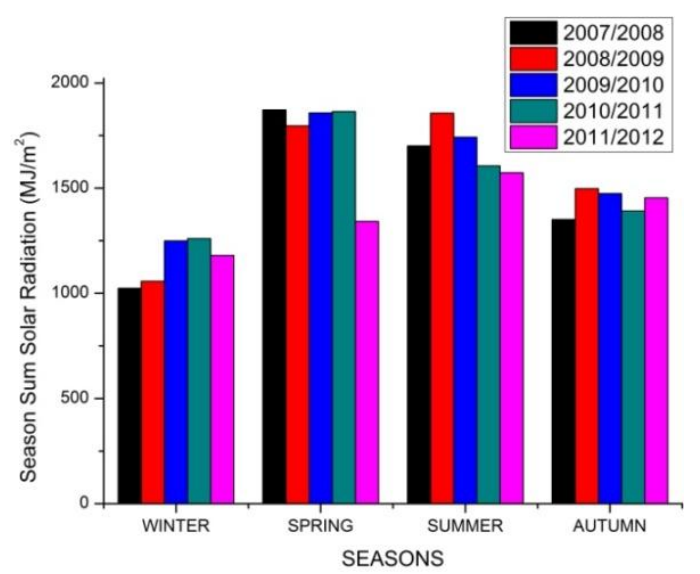

Figure 1.c: Seasonal Sum GSR of Kathmandu

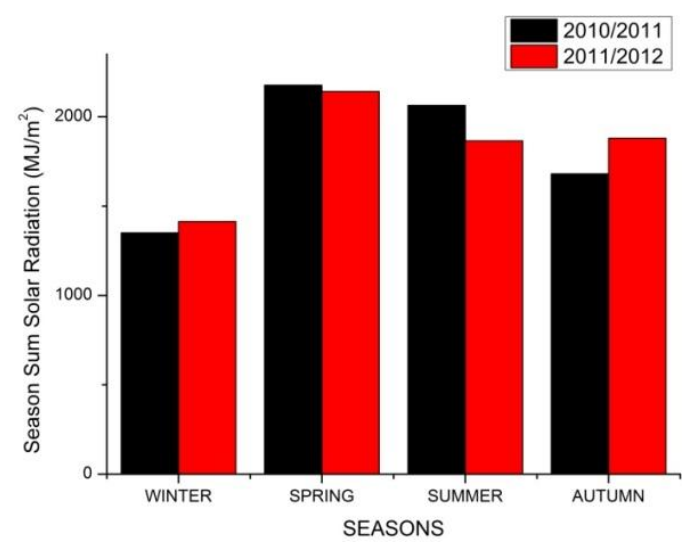

Figure 1.e: Seasonal Sum GSR of Jumla

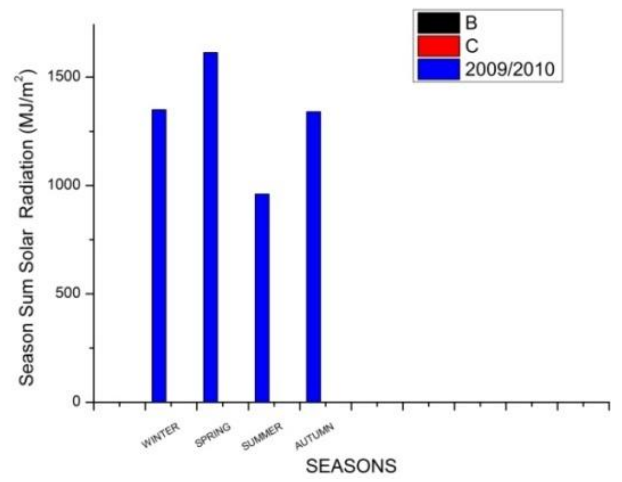

Figure 1.b: Seasonal Sum GSR of Lukla

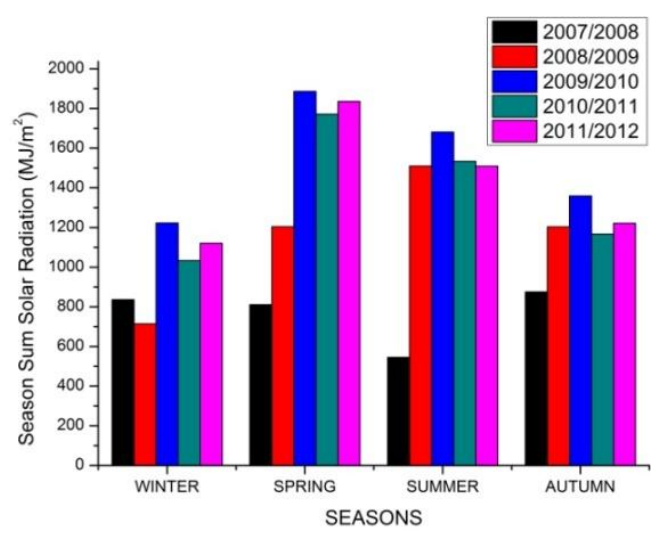

Figure 1.d: Seasonal Sum GSR of Pokhara

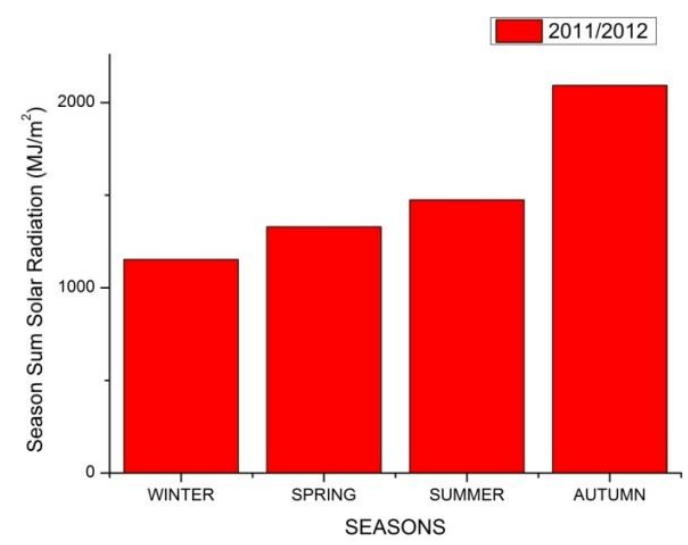

Figure 1.f: Seasonal Sum GSR of Simikot 


\subsection{Yearly Variation of Solar Radiation}

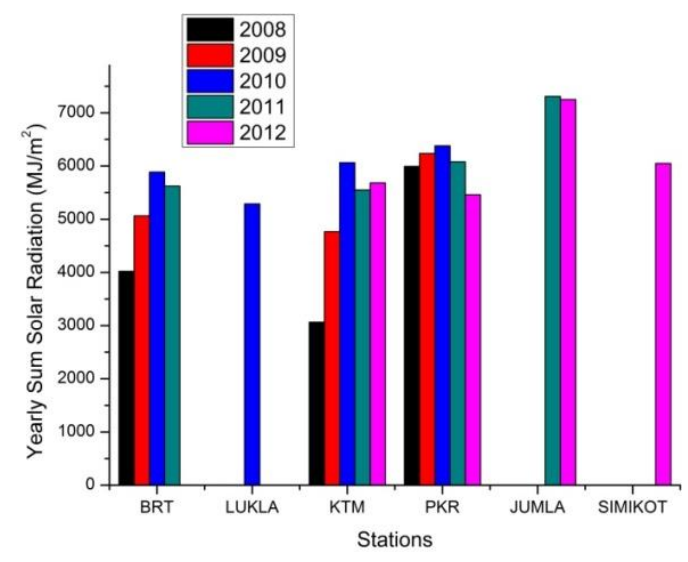

Figure 2.a: Yearly sum GSR of different sites

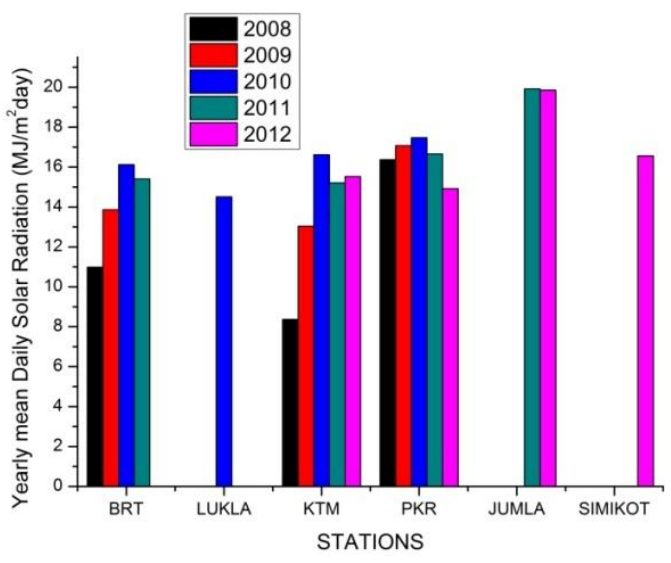

Figure 2.b: Yearly mean daily GSR for different sites

Figure 2.a and 2.b are the plotting of yearly sum and yearly mean daily global solar radiation of different sites of Nepal and their comparison. The plots shows the minimum value of yearly sum $3063.69 \mathrm{MJ} / \mathrm{m}^{2}$ and yearly mean daily global solar radiation $8.37 \mathrm{MJ} / \mathrm{m}^{2}$ day in 2008 were recorded for Kathmandu and maximum value of yearly sum $7308.8 \mathrm{MJ} / \mathrm{m}^{2}$ and yearly mean daily global solar radiation $19.92 \mathrm{MJ} / \mathrm{m}^{2}$ day were observed in 2011 for Jumla. It was shown that more solar radiation was recorded in 2010 at Biratnagar, Lukla, Kathmandu and Pokhara that characterize the relatively more clear skies and more sunny days throughout the country.

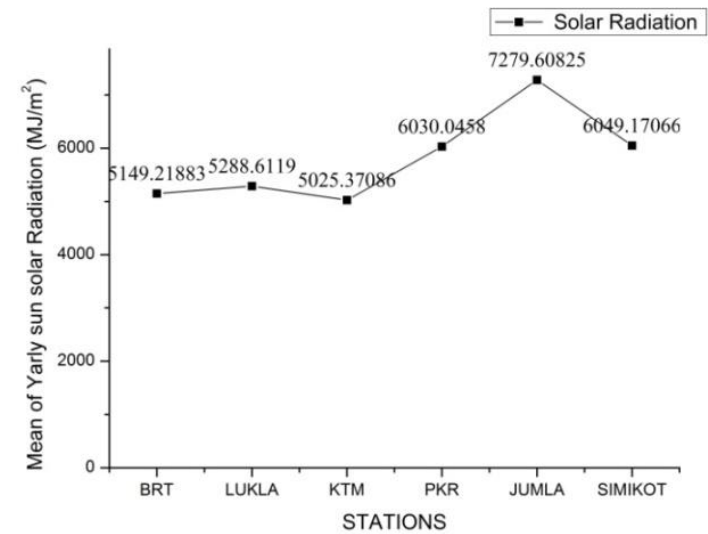

Figure 2.c: Mean of yearly sum GSR for different sites

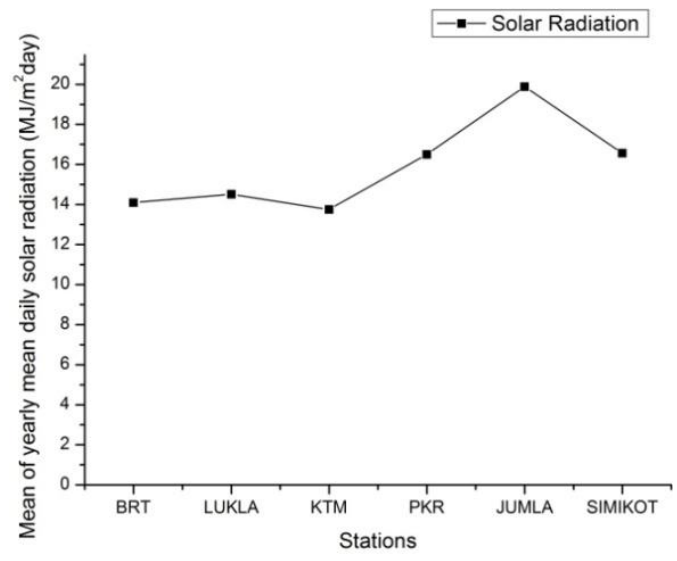

Figure 2.d: Mean of yearly mean daily GSR for different sites 
Plots of mean of yearly sum of global solar radiation and mean of yearly mean daily global solar radiation, in figure 2.c, $\mathrm{d}$, of six locations proved the maximum solar insolation falls at Jumla among these locations and minimum value at Kathmandu. Mean of yearly mean daily solar radiation were found to be $14.095 \mathrm{MJ} / \mathrm{m}^{2}$ day, $14.51 \mathrm{MJ} / \mathrm{m}^{2}$ day, $13.753 \mathrm{MJ} / \mathrm{m}^{2}$ day, 16.499 $\mathrm{MJ} / \mathrm{m}^{2}$ day, $19.884 \mathrm{MJ} / \mathrm{m}^{2}$ day, $16.562 \mathrm{MJ} / \mathrm{m}^{2}$ day for Biratnagar, Lukla, Kathmandu, Pokhara, Jumla, and Simikot respectively. The value of Biratnagar and Simikot are slightly different from the value provided by the final report [3]. The plot 2.e and the data for the 19 different locations cover almost parts of Nepal show that national average global insolation of Nepal is 4.66 $\mathrm{kWh} / \mathrm{m}^{2}$ day which is slightly different from the value $4.7 \mathrm{kWh} / \mathrm{m}^{2}$ day provided by final report [3]. This value is greater than the $4.39 \mathrm{kWh} / \mathrm{m}^{2}$ day measured by Solar Energy Research Laboratory, Department of Physics, Silpakorn University, Thailand for Lao PDR [15] and less than $5.1 \mathrm{kWh} / \mathrm{m}^{2}$ day, selected sites of Nigeria, measured by [13]. The measurements showed that global solar radiation is dependent on location, altitude, time of the day, month, season and year as well.

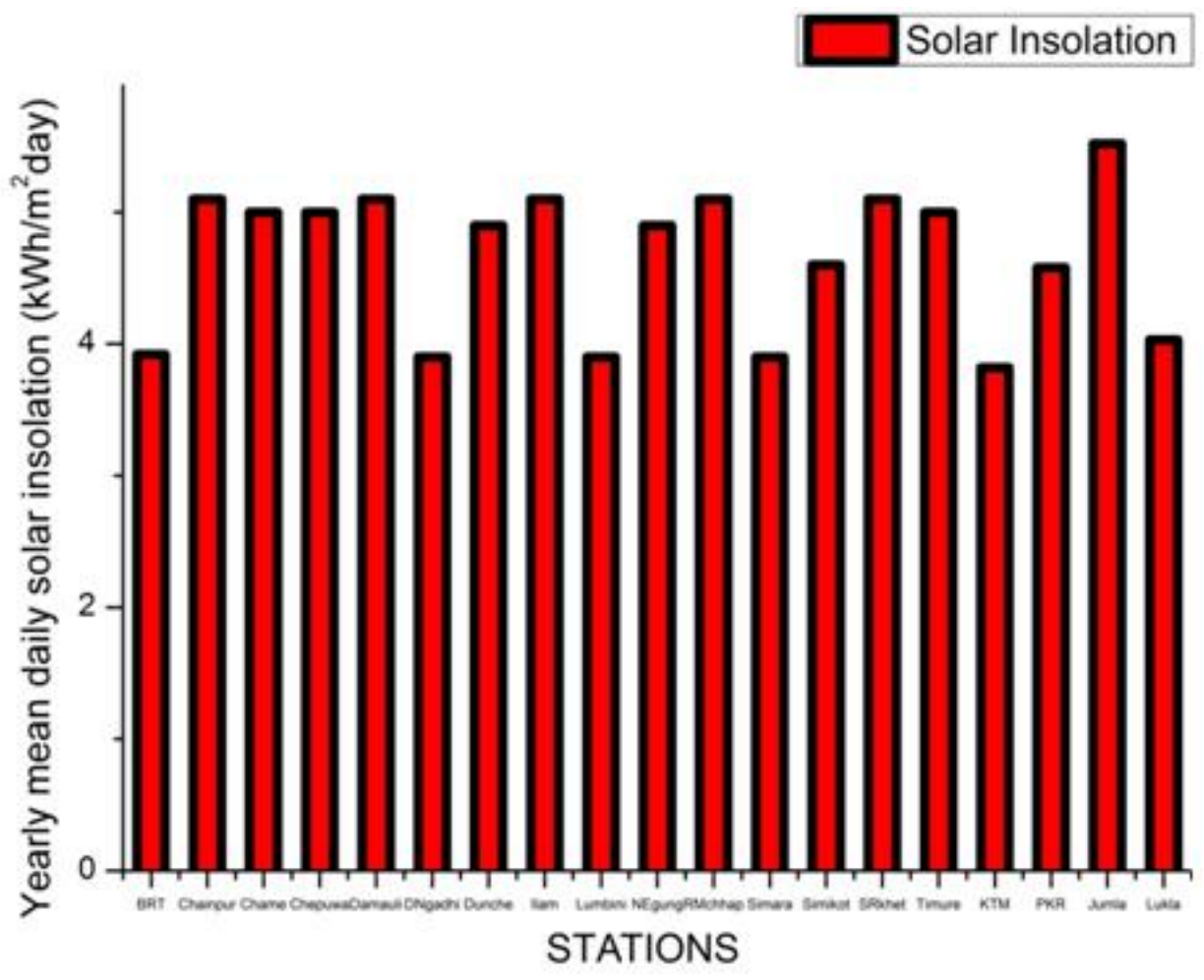

Figure 2.e: Yearly mean daily global solar radiation for 19 different sites in Nepal

\section{Conclusions}

Monthly sum minimum global solar insolation were recorded as $285 \mathrm{MJ} / \mathrm{m}^{2}$ in Jan for Biratnagar, $242.33 \mathrm{MJ} / \mathrm{m}^{2}$ in August for Lukla, $311.00 \mathrm{MJ} / \mathrm{m}^{2}$ in December for Kathmandu, $360.60 \mathrm{MJ} / \mathrm{m}^{2}$ in December for Pokhara, $436.50 \mathrm{MJ} / \mathrm{m}^{2}$ in December and $366.10 \mathrm{MJ} / \mathrm{m}^{2}$ in December for Simikot. Likewise, monthly sum maximum global solar radiation were observed as $583.40 \mathrm{MJ} / \mathrm{m}^{2}$ in May, $581.68 \mathrm{MJ} / \mathrm{m}^{2}$ in April, $537.65 \mathrm{MJ} / \mathrm{m}^{2}$ in May, $664.12 \mathrm{MJ} / \mathrm{m}^{2}$ in May, $781.36 \mathrm{MJ} / \mathrm{m}^{2}$ in May and $1233.30 \mathrm{MJ} / \mathrm{m}^{2}$ in September (Unusual value) for Biratnagar, Lukla, 
Kathmandu, Pokhara, Jumla and Simikot respectively.The minimum monthly mean daily global solar radiation (GSR) were recorded as $9.193 \mathrm{MJ} / \mathrm{m}^{2}$ day in Jan, $9.28 \mathrm{MJ} / \mathrm{m}^{2}$ day in September, 12.25 MJ $/ \mathrm{m}^{2}$ day in January, $11.60 \mathrm{MJ} / \mathrm{m}^{2}$ day in December, $14.30 \mathrm{MJ} / \mathrm{m}^{2}$ day in December, and $11.81 \mathrm{MJ} / \mathrm{m}^{2}$ day in December for Biratnagar, Lukla, Kathmandu, Pokhara, Jumla and Simikot respectively. Similarly, the maximum monthly mean daily global solar radiation were recorded as $18.82 \mathrm{MJ} / \mathrm{m}^{2}$ day in May, $19.39 \mathrm{MJ} / \mathrm{m}^{2}$ day in April, 17.34 in May, $21.42 \mathrm{MJ} / \mathrm{m}^{2}$ day in May, 25.205 MJ/m² day in May, and $41.11 \mathrm{MJ} / \mathrm{m}^{2}$ day (Unusual Data) in September for Biratnagar, Lukla, Kathmandu, Pokhara, Jumla and Simikot respectively.

The peak solar insolation occurs from April to July and least value occurs in January, February, November and December. Unusual data were recorded only in September for Simikot due to either instrumental error, or some strong light source/reflector might be present close to the instrument. It was manifested that Jumla is the location where the maximum global solar energy was observed. Moreover all the sites in Nepal are solar radiation friendly locations i.e., ample global solar radiation were recorded.

It has been shown that more solar radiation was recorded in 2010 at Biratnagar, Lukla, Kathmandu and Pokhara that characterize the relatively more clear skies and more sunny days throughout the country. The measurements have been shown that global solar radiation is dependent on location, altitude, hour of the days, month, season and year. Unusual data were recorded for Simikot only in September due to either instrumental disorder, or some powerful light source/reflector might be present close to the instrument and unexpected least values at Kathmandu indicate the more hazy skies and pollutant particulates in the atmosphere above the Kathmandu valley.

Mean of yearly mean daily solar radiation were found to be $14.095 \mathrm{MJ} / \mathrm{m}^{2}$ day, $14.51 \mathrm{MJ} / \mathrm{m}^{2}$ day, $13.753 \mathrm{MJ} / \mathrm{m}^{2}$ day, $16.499 \mathrm{MJ} / \mathrm{m}^{2}$ day, $19.884 \mathrm{MJ} / \mathrm{m}^{2}$ day, $16.562 \mathrm{MJ} / \mathrm{m}^{2}$ day for Biratnagar, Lukla, Kathmandu, Pokhara, Jumla, and Simikot respectively. The value of Biratnagar and Simikot are slightly different from the value provided by the final report [3]. Similarly the value, based on for Biratnagar $\left(9.13 \mathrm{MJ} / \mathrm{m}^{2}\right.$ day $)$, Lukla $\left(15.4313 \mathrm{MJ} / \mathrm{m}^{2}\right.$ day $)$ Kathmandu $\left(13.7113 \mathrm{MJ} / \mathrm{m}^{2}\right.$ day) and Pokhara $\left(14.3213 \mathrm{MJ} / \mathrm{m}^{2}\right.$ day) provided by [14] are also different from the value measured and presented by this study.

It was manifested that Jumla is the location where the maximum global solar energy was observed. The national average solar insolaton of Nepal is found to be $4.66 \mathrm{kWh} / \mathrm{m}^{2}$ day $(16.776$ $\mathrm{MJ} / \mathrm{m}^{2}$ day). This value is greater than the $4.39 \mathrm{kWh} / \mathrm{m}^{2}$ day value measured by Solar Energy Research Laboratory, Department of Physics, Silpakorn University, Thailand for Lao PDR [15] and less than $5.1 \mathrm{kWh} / \mathrm{m}^{2}$ day, representing selected high potential sites of Nigeria, measured by [13]. All the sites in Nepal are solar radiation friendly locations i.e., abundant global solar radiation were recorded in Nepal. So, Nepal is a high insolation country, and it has high solar energy potential as compared to other parts of the world. Thus, solar farming in this country is strongly recommended to resolve the environmental, economic, and energy issues.

\section{Acknowledgements}

Authors gratefully express sincere thanks to University Grant Commission, Nepal for providing assistance in the form of scholarship and assistantship for this research work and are indebted to Department of Hydrology and Meteorology/GoN and Solar Radiation and Aerosol in Himalaya Region (SAHR) project, Pulchowk, Nepal for making the data available. 


\section{References}

[1] Adhikari, K. R., Bhattarai, B. K., and Gurung, S. (2013). Estimation of Global Solar Radiation for Four Selected Sites in Nepal Using Sunshine Hours, Temperature and Relative Humidity, Journal of Power and Energy Engineering, 1(3), 1-9.

[2] Adhikari, K. R., Bhattarai, B. K., and Gurung, S. (2013). Global Solar Radiation On Horizontal Surface at Pokhara, Nepal. Oodbodhan, 67-72, TUTA Pashchimanchal Campus Unit.

[3] Center for Energy Studies (2005). Solar and Wind Energy Resource Assessment in Nepal, Kathmandu, Alternate Energy Promotion Center, Ministry of Environment, Science and Technology, GoN.

[4] Chegaar, M., and Chibani, A. (2000). A Simple Method for Computing Globle Solar Radiation. Rev. Energ. Ren. : Chemss, 111-115.

[5] Duffie, J., and Beckman, W. (2006). Solar Engineering of Thermal Process, Third Edition, John Willey and Sons, New York.

[6] IEA (2011). Clean Energy Progress Report, International Energy Agency.

[7] Iqbal, M. (1983). An introduction to solar radiation, Academic press, New York.

[8] Liou, K. (2002). An Introduction to Atmospheric Radiation, Second edition, Academic press, New York.

[9] MOF, (2012). MOF Annual Report, Ministry of Forest, GoN.

[10] NAPA, (2010). National Adaptation Programme of Action (NAPA), Ministry of Environment, GoN.

[11] NEA (2011). Nepal Electricity Authority Annual Report, Ministry of Energy, GoN.

[12] Nepal Energy Situation, (2011). Retrieved July, 2013 from energypedi.info.wiki: https://www.energypdia.info/wiki.

[13] Oliyanka, S. (2011). Estimation of Global Solar Radiations for Selected Sites in Nigeria, International Journal of Energy and Environmental Engineering, 13-33.

[14] Poudyal, K., Bhattarai, B. K., Sapkota, B. K., and Kjeldstad, B. (2010). Solar Radiation Potential at Four Sites of Nepal, Journal of the Institute of Engineering, 8(3), 189-197.

[15] Solar Energy Research Laboratory, (2010). Assessment of Solar Radiation Potential for Lao PDR, Department of Alternative Energy Development and Efficiency, Thailand and Deparment of Electricity, Lao PDR.

[16] Torgul, I. T. (2009). Estimation of Solar Radiation from Angstoms coefficients by Using Geographycal and Meteorological Data in Bishket, Kyrgyzstan, J. of Thermal Science and Technology, 99-108.

[17] Wang, K., Dickinson, R., Wild, M., and Liang, S. (2012). Atmospheric Impacts on Climatic Variability of Surface Incident Solar Radiation, Atmospheric Chemistry and Physics, 9581-9592.

[18] WECS (2010). Energy sector Synopsys Report, Nepal, Energy Sector Synopsis Report, Nepal. 